MATHEdunesa

Jurnal IImiah Pendidikan Matematika Volume 9 No. 2 Tahun 2020

ISSN :

\title{
PROFILE OF STUDENT'S REFLECTIVE THINKING IN SOLVING PISA MATHEMATICS PROBLEMS BASED ON GENDER DIFFERENCES
}

\author{
Annisa Rizqa Aulia \\ Departement of Mathematics, Faculty of Mathematics and Natural Sciences, Universitas Negeri Surabaya \\ e-mail: annisaaulia16030174047@mhs.unesa.ac.id \\ Raden Sulaiman \\ Departement of Mathematics, Faculty of Mathematics and Natural Sciences, Universitas Negeri Surabaya \\ e-mail: radensulaiman@unesa.ac.id
}

\begin{abstract}
Reflective thinking ability is important in solving problems so students can easily determine the right strategy to solve problems using the knowledge and experience they have. Reflective thinking is an activity or mental process using knowledge or experience with an awareness of what is known and needed that is done repeatedly and with full consideration of beliefs supported by clear reasons to find a decision or solve a problem. This study uses four stages of reflective thinking which include (1) describing experiences based on problems, (2) elaborating experiences to form a solution strategy, (3) analyzing experiences based on solutions, and (4) evaluating experiences based on the solutions. The purpose of this study is to describe the reflective thinking profile of male and female middle school students in solving PISA mathematics problems. The participant of this research are male and female students of grade VIII in Surabaya. The method used in this study is a qualitative explorative descriptive study. The results showed that at the stage of describing experiences based on problems, male and female students use their experiences in solving problems. In the stage of elaborating experience to form a strategy for solving, male students specifically identify mathematical concepts contained in the problem, male and female students choose the right formula and strategy to solve the problem. At the stage of analyzing experiences based on resolution, male and female students explain the answers given, male students mention strengths and weaknesses related to problem solving. In the stage of evaluating experience based on the solutions, male and female students state the reasons why the answers given have answered the problem, female students test whether the solution done has answered the problem.
\end{abstract}

Keywords: Profile, Reflective Thinking, Mathematics Problems, PISA, Gender

\section{INTRODUCTION}

Mathematics is one of knowledges that has an important role in the development of science and technology. Along with its important role, mathematics also has links with other sciences. Mathematics is given to students starting from elementary school to college, so mathematics has many roles to equip students. According to the Regulation of the Minister of Education and Culture of the Republic of Indonesia (Permendikbud No. 35 Tahun 2018), education in Indonesia has the aim to develop the ability to think in students' reflective thinking as a potential to solve social problems in society. Reflective thinking is important to develop in students to familiarize students in terms of reflecting their activities in daily life, especially in learning in school and solving problems in everyday life. The statement is in accordance with the opinion of Muin (2011: 22) regarding the importance of reflective thinking that in teaching and learning, to develop reflective thinking skills the teacher can provide exercises for students with unusual problems or problems. Selected questions can train students in analyzing a problem in order to find answers with appropriate solutions.
Reflective thinking is something that is done actively, persistently, and full of consideration of beliefs supported by clear reasons and can make conclusions / decide on a solution to the problem given (John Dewey, 1933). Reflective thinking is carried out with consideration and confidence with strong reasons in order to obtain a solution to a problem. Taggart \& Wilson (2005: 1) stated that reflective thinking is the process of making informed and logical decisions on educational matters, the assessing the consequences of those desicions. Reflective thinking is the process of making logical and informed decisions about education, and can assess the consequences of those decisions. So, reflective thinking is a process carried out in making decisions logically and is able to estimate the consequences. Reflective thinking is thinking with the process of confusion so that an investigation is carried out repeatedly to find a solution to a problem (Suharna, 2018: 229). Reflective thinking occurs when there is confusion in a person that encourages a person to carry out repeated investigations so that a solution to a problem is obtained. From the explanation of some of the experts above about the reflective thinking process, researchers can conclude that reflective thinking is an activity or mental process 
using knowledge or experience with awareness of what is known and needed that is done repeatedly and with full consideration of beliefs supported by clear reasons to find a decision or solving a problem.

Reflective thinking has several phases. According to Lee (2000), there are six phases of reflective thinking, which are as follows:

1. Problem context

2. Problem definition

3. Seeking possible solution

4. Experimentation

5. Evaluation

6. Acceptance/rejection

Whereas Dewey (Rodgers, 2002) states that there are six phases in reflective thinking, namely:

1. An experience

2. Spontaneous interpretation of the experience

3. Naming the problem or question that arise out the experience

4. Generating possible explanations for the problem or question posed

5. Ramifying the explanation into full-blown hypotheses

6. Experimenting or testing the selected hypotheses

Meanwhile Rodgers (2002) packed six phases of reflective thinking by Dewey into four phases, such as, presence to experience, description of experience, analysis of experience, intelligent action/experimentation. Furthermore Agustan, et al (2017) synthesized the stages of reflective thinking from several experts, so that the stages of reflective thinking were obtained into four stages representing the stages of several experts. This study uses four stages, namely, (1) describing experiences based on problems, (2) elaborating experiences to form a solution strategy, (3) analyzing experiences based on solutions, and (4) evaluating experiences based on the solutions.

The teacher can provide exercises for students with unusual problems or problems in learning to develop reflective thinking skills. Selected questions can train students in analyzing a problem in order to find answers with appropriate solutions. Further, Juhaevah (2017) said that reflective thinking ability is important in problem solving so students can easily determine the right strategy for problem solving by using the knowledge they already have. This is reinforced by Gurol's statement that reflective thinking is used to encourage thought processes in problem solving, because it provides opportunities for learning and can think of the best strategies for problem solving (Masamah et al., 2015).

In solving problems, students must understand the problem they are going to solve. Polya (2004: 6) stated that "the problem should be well chosen, not too difficult and not too easy, natural and interesting, and some time should be allowed for natural and interesting presentation." In mathematics there are various kinds of problems. These problems must be selected in accordance with the learning objectives that will be given to students so that learning can be conveyed appropriately to students.

Some experts have proposed methods for solving problems. One of them is Polya (2004: 5-6) in his book written that problem solving requires coherent steps in order to get the best problem solving strategy that is understanding the problem, compiling a problem solving plan, implementing a problem solving plan, and checking again. Students must be able to solve the problems given by the teacher in order to achieve the desired learning goals.

Teachers can train students with problems in the process of interpreting to improving student's reflective thinking because in the process of interpreting, students can effectively reflect the solutions and conclusions obtained in solving problems. In addition, with these problems, students can provide answers and conclusions that are correct and logical. This is supported by the OECD (2019: 77) which states that "The interpreting process occurs how effectively students are able to reflect upon mathematical solutions or conclusions, interpret them in the context of a real-world problem, and determine whether the results or conclusions are reasonable. " Therefore, the mathematical problem that will be used in this study is the PISA mathematics problem.

Many factors can influence the process and learning outcomes of students in schools one of which is the existence of gender differences as explained from several facts that exist in the realm of education. It can be found in the results of PISA 2012, that male students are superior in the process of formulating content on space and form, while female students' performance is less in the process of using and interpreting uncertainty and data content. Although male and female students are at the same level, female students are more likely to show signs of anxiety about mathematics and lower levels of mathematics independence and confidence (OECD, 2014). Several studies have been conducted between men and women in problem solving and reflective thinking, one of which is a study conducted by Demirel and Derman (2015). This research was conducted in Turkey with the aim of the study being to examine the relationship between students' reflective thinking skills on problem solving and their attitudes towards mathematics. The study found that there was no significant difference between students' reflective thinking skills on problem solving and gender. However, there are significant differences in the height of male students in terms of attitudes towards mathematics. In addition, there is research conducted by Nuralam and Yani (2019) resulting that female students are better than men in solving mathematical problems. In contrast to this, Zhu (2007: 199) revealed that differences in solving mathematical problems, have been believed to be important factors. Where in the standard mathematics test, male students have better mathematical problem solving skills than female students who are given to a group of highability students. Zhu's opinion indicates that there are differences in the performance or ability of men and women to influence the process of problem solving. From some of the results of the research above regarding differences in sex in learning and performance in mathematics, found different results that need further research on it. Based on the above explanation, a research entitled "Profile of Student's Reflective Thinking in Solving PISA Mathematics Problems based on Sex Differences". 


\section{METHOD}

This study is to describe students' reflective thinking in solving PISA mathematics problems in terms of gender differences. This research is a descriptive qualitative exploratory study. Qualitative research emphasizes more on meaning than generalization (Sugiyono, 2015: 19). Descriptive research is a study conducted with the main objective to provide an image or description of an object objectively. The subjects of this study consisted of two students, namely one male student and one female student at 39 Public Middle School (SMP) Surabaya in class VIII. The data in this study were collected through three stages, namely carrying out a math ability test, carrying out a PISA math problem solving test, and conducting an interview. Mathematical ability tests are used to obtain subjects with high and equal mathematical abilities. Subjects had an equivalence score between 80 and 100 on the given mathematics ability test While the PISA math problem solving test and conducting interviews are used to obtain qualitative data about students' reflective thinking in solving PISA math problems. Mathematics ability test data includes the results of the work of students in one class who are then given an assessment or score to determine the selection of subjects who have a score of $80<$ score obtained $\leq 100$. This math ability test is given to one of the classes in class VIII students.

The research instrument consisted of mathematics ability tests, problem solving tests, and interview guidelines compiled and then consulted with the supervisor before conducting validation. After obtaining approval from the supervisor, the instrument was validated by a mathematics education lecturer. Answer sheets of students' math ability tests are analyzed based on the assessment guidelines that have been validated by the validator. After obtaining the results of mathematical abilities from students, one male student and one female student were chosen by considering the students' communication skills based on the recommendations from the class teacher. Next, instrument data to reveal the reflective thinking profile of students was obtained by written tests, namely problem solving tests with PISA questions and interview results. Problem solving test instruments are arranged based on the PISA question profile as follows.

Table 1. Profile of PISA Problems

\begin{tabular}{|l|l|l|l|}
\hline Problem & Content & Context & Process \\
\hline $\begin{array}{l}\text { Climbing } \\
\text { Mount } \\
\text { Fuji }\end{array}$ & $\begin{array}{l}\text { Change and } \\
\text { Relationship }\end{array}$ & General & Formulating \\
\hline $\begin{array}{l}\text { Sailing } \\
\text { Ships }\end{array}$ & $\begin{array}{l}\text { Space and } \\
\text { Shape Scientific }\end{array}$ & \\
\hline $\begin{array}{l}\text { Faulty } \\
\text { Players }\end{array}$ & $\begin{array}{l}\text { Uncertainty } \\
\text { and data }\end{array}$ & Occupation & Interpreting \\
\hline
\end{tabular}

After arranged the profile as in Table 1. Next compiled the instrument of problem solving tests that have been validated, revised and made it possible to describe the reflective thinking carried out by the subject. After that, giving a problem solving test to the subjects, the interview activity is carried out using a reference to the interview guidelines, then the results of the TPM and the interview are analyzed based on the reflective thinking indicators used in this study.
The following are reflective thinking indicators in this study which were adapted from the research of Agustan, et al., 2017.

Table 2. Indicators of Reflective Thinking (Agustan, et al., 2017)

\begin{tabular}{|c|c|c|}
\hline Stage & Indicator & Code \\
\hline \multirow{3}{*}{$\begin{array}{l}\text { Describing } \\
\text { experiences } \\
\text { based on } \\
\text { problems }\end{array}$} & $\begin{array}{l}\text { a. Communicating problems } \\
\text { with own language }\end{array}$ & D1 \\
\hline & $\begin{array}{l}\text { b. Expressing mathematical } \\
\text { concepts related to the } \\
\text { problem }\end{array}$ & D2 \\
\hline & $\begin{array}{l}\text { c. Associate problems with } \\
\text { his or her experience in } \\
\text { solving similar problems }\end{array}$ & D3 \\
\hline \multirow{3}{*}{$\begin{array}{l}\text { Elaborating } \\
\text { on } \\
\text { experiences } \\
\text { to form } \\
\text { completion } \\
\text { strategies }\end{array}$} & $\begin{array}{l}\text { a. Identify mathematical } \\
\text { concepts contained in the } \\
\text { problem specifically }\end{array}$ & EB1 \\
\hline & $\begin{array}{l}\text { b. Choose the right formula } \\
\text { and strategy to solve the } \\
\text { problem }\end{array}$ & EB2 \\
\hline & $\begin{array}{l}\text { c.Explain the difficulties } \\
\text { encountered when } \\
\text { implementing strategies in } \\
\text { solving problems }\end{array}$ & EB3 \\
\hline \multirow{3}{*}{$\begin{array}{l}\text { Analyzing } \\
\text { experiences } \\
\text { based on } \\
\text { solutions }\end{array}$} & $\begin{array}{l}\text { a. Explain the answers that } \\
\text { have been given }\end{array}$ & A1 \\
\hline & $\begin{array}{l}\text { b. Mention the strengths and } \\
\text { weaknesses related to the } \\
\text { solution }\end{array}$ & $\mathrm{A} 2$ \\
\hline & $\begin{array}{l}\text { c. Clarify the efforts that can } \\
\text { be made to overcome } \\
\text { weaknesses associated } \\
\text { with solving the problem }\end{array}$ & A3 \\
\hline \multirow{2}{*}{$\begin{array}{l}\text { Evaluating } \\
\text { experience } \\
\text { based on } \\
\text { solution }\end{array}$} & $\begin{array}{l}\text { a.Express the reasons why } \\
\text { the answers given have } \\
\text { answered the problem }\end{array}$ & EV1 \\
\hline & $\begin{array}{l}\text { b. Test whether the solution } \\
\text { has been solved }\end{array}$ & EV2 \\
\hline
\end{tabular}

Problem solving test data and the results of interviews that have been obtained, analyzed using data analysis techniques. Data analysis is into a pattern, choosing what is important and what will be studied, and making conclusions so that it is easily understood by oneself and others (Sugiyono, 2015: 335). Data analysis techniques used in problem solving test data and interview data refer to the analysis steps according to Sugiyono (2015: 337) including three stages, namely data reduction, data presentation, and drawing conclusions.

\section{ANALYSIS AND DISCUSSION}

The reflective thinking data of students in solving PISA mathematical problems in terms of gender differences consists of data on the answers to problem solving and the results of interviews conducted by male LA and female PU. The results of interviews conducted with research subjects were transcribed and coded to make it easier for researchers to present data and analyze it. An explanation of the code in the results of the interview is presented in the following table. 
Table 3. Interview Code

\begin{tabular}{|c|c|}
\hline Code & Explanation \\
\hline \multirow{4}{*}{ Pxxxxxx } & $\begin{array}{l}\mathrm{P} \text { in the first digit represents the } \\
\text { researcher conversation code. }\end{array}$ \\
\hline & $\begin{array}{l}\text { Xx on the second and third digits state } \\
\text { the gender of the research subject. LA } \\
\text { for men and PU for women. } \\
\text { For example the PLA stated the } \\
\text { researcher's conversation with the male } \\
\text { subject. }\end{array}$ \\
\hline & $\begin{array}{l}x \text { in the fourth digit states the type of } \\
\text { PISA Mathematical Problems in the } \\
\text { study. F for formulating, E for } \\
\text { employing, I for interpreting. } \\
\text { For example PxxF states the } \\
\text { researcher's conversation on the } \\
\text { formulating problem. }\end{array}$ \\
\hline & $\begin{array}{l}\mathrm{xx} \text { in the fifth and sixth digits indicate } \\
\text { the sequence of interview activities. }\end{array}$ \\
\hline \multirow{4}{*}{ Sxxxx } & $\begin{array}{l}\mathrm{S} \text { in the first digit represents the } \\
\text { conversation code of the research } \\
\text { subject. }\end{array}$ \\
\hline & $\begin{array}{l}\text { Xx on the second and third digits state } \\
\text { the gender of the research subject. } \\
\text { For example SLA states male subject } \\
\text { conversation. }\end{array}$ \\
\hline & $\begin{array}{l}x \text { on the fourth digit indicates the type } \\
\text { of PISA Mathematical Problem in the } \\
\text { study. F for formulating, E for } \\
\text { employing, I for interpreting. } \\
\text { Suppose SxxF expresses the subject's } \\
\text { conversation on formulating problems. }\end{array}$ \\
\hline & $\begin{array}{l}\mathrm{xx} \text { in the fifth and sixth digits indicate } \\
\text { the sequence of interview activities. }\end{array}$ \\
\hline
\end{tabular}

1. Results and Analysis of Reflective Thinking Data for LA Subject in Solving PISA Mathematical Problems a. Reflective Thinking Profile of LA in Solving Formulating Problem

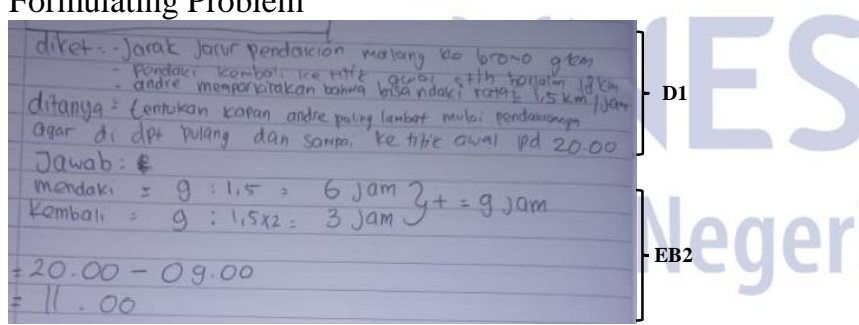

Figure 1. LA's Answer to Formulating Problem

From Figure 1, it is known that LA writes information that is known and asked about the problem. LA mentions distance and speed as information that will be used to answer the problem being asked. LA does not write the initial formula related to time, speed, and distance and also does not write the conclusions of the settlement that has been done. The rest of the explanation related to the settlement that LA did can be seen from the interview excerpt that was conducted.
Table 4. Transcript of the LA Interview on the Formulating Problems

\begin{tabular}{|c|c|}
\hline $\begin{array}{c}\text { Interview } \\
\text { Code }\end{array}$ & Interview Excerpt \\
\hline PLAF14 & $\begin{array}{l}\text { Setelah kamu menerapkan } \\
\text { strategi atau cara yang kamu } \\
\text { gunakan, jelaskan jawabanmu } \\
\text { dalam menyelesaikan masalah } \\
\text { itu? }\end{array}$ \\
\hline SLAF14 & $\begin{array}{l}\text { Jadi langkah pertama aku } \\
\text { hitung dulu, yang pendaki kan } \\
1,5 \mathrm{~km} \text {, terus jaraknya } 9 \mathrm{~km} \\
\text { kan rumusnya itu waktu }= \\
\frac{\text { jarak }}{\text { kecepatan }, \text { jadi } 6 \text { jam, yang }} \\
\text { menurun itu } 2 \times \text { nya jadi } \frac{9}{3}= \\
\text { 3jam. Kalau tak tambah itu } 9 \\
\text { jam nah terus waktunya tiba } \\
\text { jam } 8 \text { lah jadi jam } 8 \text { tak } \\
\text { kurangi } 9 \text { jam, lah itu jam } 11 \\
\text { jawabannya. }\end{array}$ \\
\hline
\end{tabular}

Based on interviews, in the stage of describing experiences, LA restated what was known and asked in the problem. Then LA revealed mathematical concepts related to the problem namely distance, time, and speed. LA remembers having worked on a similar problem. LA stated that it would be difficult to work on problems when forgetting the formula.

In the stage of elaborating experience to form a solution strategy, LA revealed the mathematical concepts contained in the problem namely distance, time, and speed. LA revealed the formula and strategy used to solve this problem and revealed the reason for choosing the formula and strategy because he thought the method he chose was easier and easier to calculate. LA states the difficulties encountered when applying formulas and strategies to the problem that is if it forgets the formula or multiplication and reveals the reason because LA rarely resolves such problems.

In the stage of analyzing experiences based on completion, LA explains the answers that have been completed. Next, LA revealed the strengths and weaknesses of the settlement that had been done. The advantages that LA mentioned are that it is easy and uncomplicated. According to him the weakness is the way LA wrote unclear, difficult to understand by people who will correct it. LA also revealed how to improve the weaknesses that are owned when resolving the problem, namely by improving the solution so that it is easily understood by others.

At the stage of evaluating experience based on the settlement made, LA is confident of the answers and the solutions that it has done. Next, LA has also tested whether the answers and resolutions that were carried out were right or 
wrong, namely by recalculating the settlement that had been done.

b. Reflective Thinking Profile of LA in Solving Employing Problem

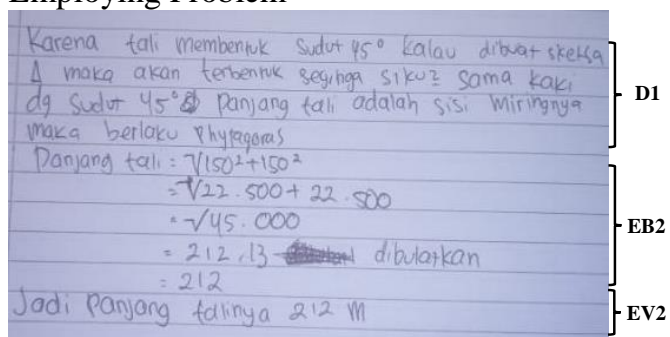

Figure 2. LA's Answer to Employing Problem

From Figure 2, it appears that LA does not write what is asked about the problem. This shows a lack of consideration and deep thought. This is in accordance with the OECD (2014) that men have a greater curiosity than women, it appears that the subject is in a hurry in solving problems so the written resolution is less clear. LA writes logical reason using the phytagorean formula, which is from two $45^{\circ}$ angles found on the isosceles right triangle. Then, LA did the settlement using the phytagorean formula. LA does not write down how to find the root value of these numbers. Then, LA also wrote a conclusion about the settlement he was doing. The rest of the settlement done by LA can be seen from the interview excerpt below.

Table 5. Interview Excerpt of LA in Solving Employing Problem

\begin{tabular}{|c|c|}
\hline $\begin{array}{l}\text { Interview } \\
\text { Code }\end{array}$ & Interview Excerpt \\
\hline PLAE15 & $\begin{array}{l}\text { Setelah } \\
\text { strategi tersebut jelaskan } \\
\text { jawabanmu } \\
\text { menyelesaikan } \\
\text { tersebut. }\end{array}$ \\
\hline SLAE15 & $\begin{array}{l}\text { Jawabanku sama seperti } \\
\text { yang di atas itu, } 150^{2}+ \\
150^{2} \text { terus } 45000 \text { diakar } \\
\text { jadi } 212,13 \text { terus tak } \\
\text { bulatkan jadi } 212 \text {. }\end{array}$ \\
\hline
\end{tabular}

Based on interviews conducted, LA explained what was known and asked about the problem. LA explained to the problem asking about the length of the rope, then the concept that LA discovered was phytagoras and about the degree of angles. Next, LA has encountered this problem, according to him, this problem is rather difficult because when the material was given, LA had difficulty understanding the material.

Based on the interview, when elaborating on the experience to create a settlement strategy, LA revealed the concepts needed to solve this problem based on his experience and could link the concepts to the problem ([SLAE07] [SLAE08]). The further information he has obtained, LA mentions the formulas and strategies used and the reasons for choosing them, and reveals the difficulties he faces in compiling the use of those formulas and strategies.

At this stage, in analyzing experiences based on problem solving, LA explains how to solve and answer the problem. LA revealed its strengths and weaknesses in its resolution. Its strengths are that the method chosen is concise and its weakness is difficult to understand. Next, LA revealed a way to overcome these weaknesses by studying this material again.

At this phase, in evaluating the experience based on the settlement carried out, LA believes that the solution and the answers given have answered the question. LA also revealed a strategy to find out whether or not the settlement was done by reviewing the notes or material then try to count again.

c. Reflective Thinking Profile of LA in Solving Interpreting Problem

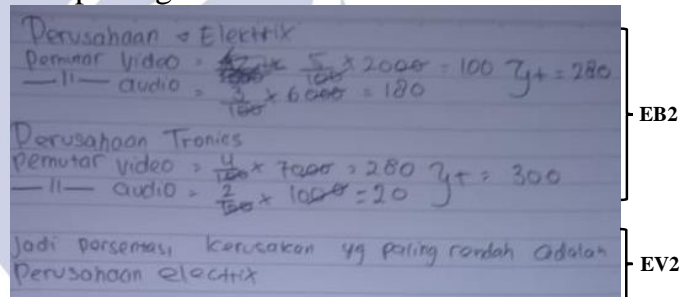

Figure 3. LA's Answer in Solving Interpreting Problem

Based on Figure 3, LA does not write what is known and asked about the problem, LA immediately writes a solution to solve the problem by counting one by one the number of audio and video players in each company and then adding up the number of damaged products in each company without recalculating the percentage damage to each company. The rest, solving the problem is explained verbally by LA in the interview excerpt below.

Table 6. Interview Excerpt of LA in Solving Interpreting Problem

\begin{tabular}{|c|l|}
\hline Interview Code & \multicolumn{1}{|c|}{ Interview Excerpt } \\
\hline PLAI14 & $\begin{array}{l}\text { Setelah kamu menerapkan } \\
\text { strategi atau cara yang } \\
\text { kamu gunakan, jelaskan } \\
\text { jawaban dan penyelesaian } \\
\text { dalam menyelesaikan } \\
\text { masalah tersebut? }\end{array}$ \\
\hline SLAI14 & $\begin{array}{l}\text { Jawabanku ini yaitu } \\
\text { dengan cara yang pertama, } \\
\text { aku hitung electrix dulu }\end{array}$ \\
\hline
\end{tabular}




\begin{tabular}{|l|l|}
\hline dari persentasenya itu yang \\
video 100 terus audio 180 \\
terus ditambah hasilnya \\
280 lalu tronics yang video \\
280 terus audio 20, \\
ditambah hasilnya 300. \\
Jadi electrix yang paling \\
rendah.
\end{tabular}

In the phase of describing experiences based on problems, LA explains again about the problem, which is to mention what is known and asked. Next. LA reveals the concept or material that is in the problem, namely the percentage. LA stated that he had encountered a problem like this before and he thought this problem was easy because he could guess how to solve it, and in the beginning LA said it was difficult to understand the problem. This is in line with the statement by Hughes (2012) that girls are superior in language skills because they read and write more. It appears that the subject has difficulty understanding the given problem.

Table 7. Transcript of the LA Interview on Interpreting Problem

\begin{tabular}{|c|l|c|}
\hline $\begin{array}{c}\text { Interview } \\
\text { Code }\end{array}$ & \multicolumn{1}{|c|}{$\begin{array}{c}\text { Interview } \\
\text { Excerpt }\end{array}$} & $\begin{array}{c}\text { Indicator } \\
\text { Code }\end{array}$ \\
\hline PLAI08 & $\begin{array}{l}\text { Berdasarkan } \\
\text { pengalaman yang } \\
\text { kamu miliki, kira- } \\
\text { kira konsep atau } \\
\text { materi } \\
\text { matematikarapa } \\
\text { yang kamu } \\
\text { butuhkan untuk } \\
\text { menyelesaikan } \\
\text { masalah tersebut? }\end{array}$ \\
\hline SLAI08 & $\begin{array}{l}\text { Konsep yang aku } \\
\text { butuhkan yaitu } \\
\text { tentang perkalian, } \\
\text { dan juga persen. }\end{array}$ \\
\hline PLAI09 & $\begin{array}{l}\text { Dan apa kaitan } \\
\text { antarar konsep- } \\
\text { konsep yang kamu } \\
\text { sebutkan tadi? }\end{array}$ \\
\hline SLAI09 & $\begin{array}{l}\text { Kaitannya itu ya } \\
\text { itu cara } \\
\text { penyelesaiannya. }\end{array}$ \\
\hline
\end{tabular}

Based on the interview transcript above, at this stage, in elaborating experiences to form a settlement strategy, LA mentioned two mathematical concepts needed to solve the problem based on his experience, which is about percentage and multiplication as well as the relationship between these concepts. LA reveals the formula and method used for the problem and the reasons for choosing that method. Furthermore, LA addresses the difficulties encountered when applying the method chosen and the causes of the difficulties arising.

At this phase, in analyzing the experience based on the settlement, LA explains the answers and how the settlement has been done. LA also points out the strengths of the answers: the answers it gets are easier and faster and the weakness of the answers is that it can be wrongly entered in value. LA revealed the efforts he would make to overcome his weaknesses.

At this stage, in evaluating the experience based on the settlement made, LA is confident of the answers and the settlement that he has done and gives reasons for this. Next, LA outlines how to find out the answers he gets are right or wrong by asking people who understand better.

2. Results and Analysis of Reflective Thinking Data for PU Subject in Solving PISA Mathematical Problems

a. Reflective Thinking Profile of LA in Solving Formulating Problem

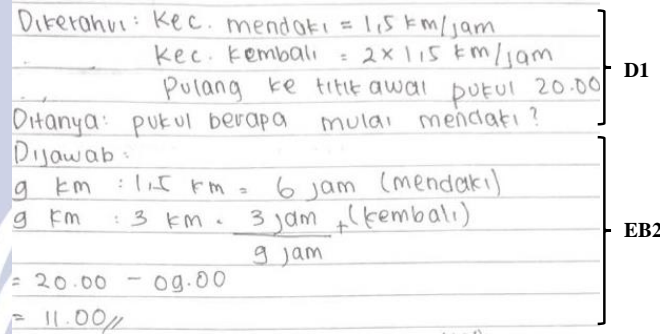

Figure 4. PU's Answer in Solving Formulating Problem

Based on Figure 4, PU writes information that is known, namely speed and time, then the question of the problem is time to start climbing. Next, PU wrote down the solution and the answers she got. PU does not write the initial formula in the method chosen. PU did not write the conclusion from the answer. PU explained the solution through the interview excerpt below.

Table 8. Interview Excerpt of LA in Solving Formulating Problem

\begin{tabular}{|c|l|}
\hline $\begin{array}{c}\text { Interview } \\
\text { Code }\end{array}$ & \multicolumn{1}{|c|}{ Interview Excerpt } \\
\hline PPUF12 & $\begin{array}{l}\text { Setelah kamu menerapkan } \\
\text { strategi atau cara yang kamu } \\
\text { gunakan, jelaskan langkah } \\
\text { penyelesaian dan jawaban } \\
\text { kamu dalam menyelesaikan } \\
\text { masalah tersebut? }\end{array}$ \\
\hline SPUF12 & $\begin{array}{l}\text { Nomor masalah satu itu kan } \\
\text { disuruh nyari waktunya yang } \\
\text { dibutuhkan untuk sampai ke } \\
\text { titik awal pendakian, pada } \\
\text { pukul 8 malam, nah pas } \\
\text { mendaki ke atas itu kan 9 km, } \\
\text { kecepatan rata-ratanya 1,5 } \\
\text { km/jam jadi } 9 \\
\text { balik itu } 6 \text { jam. Pas rata-rata nya dikali }\end{array}$ \\
\hline
\end{tabular}




\begin{tabular}{|l|l|}
\hline 2otomatis $3 \mathrm{~km} / \mathrm{jam}$, jadi ${ }^{9}$ itu \\
3 jam lah 6 jam di tambah 3 \\
jam ini 9 jam trus pada pukul \\
8 kan harus sampai ke titik \\
awal pendakian, nah itu \\
tinggal dikurangi aja dari \\
pukul 8 nya kan 20.00 \\
dikurangin 09.00 jadi ketemu \\
kalau pendaki ini harus \\
mulai setidaknya pukul 11 \\
untuk sampai ke titik awal \\
pendakian.
\end{tabular}

Based on interviews above, at the stage of describing experiences based on problems, PU revealed what was known and what was asked of the problem. PU revealed the concept she found, namely distance, time, and speed. PU also stated that it had encountered this problem before, this problem could be solved and was easy because the formula was easy to remember.

In the phase of elaborating experience to form a strategy for resolution, PU revealed the material needed for the problem based on its experience of distance, time, and speed and stated the linkages between the material mentioned that time was obtained from distance divided by speed. PU revealed the formula and method used based on information from the problem. PU stated that there were no difficulties in implementing this method.

In the phase of analyzing experiences based on solution, PU explained the ways and answers that had been done. PU revealed the strengths related to the way it was done, the formula was easy to remember and had not found any weaknesses in the solution it did.

At the stage of evaluating experience based on the settlement made, PU believes that the answers it receives have answered the questions because each step is easy to understand. PU revealed the method used to find out whether or not the settlement was correct and the answers were done by evaluating one by one if there were unreasonable justifications.

b. Reflective Thinking Profile of PU in Solving Employing Problem

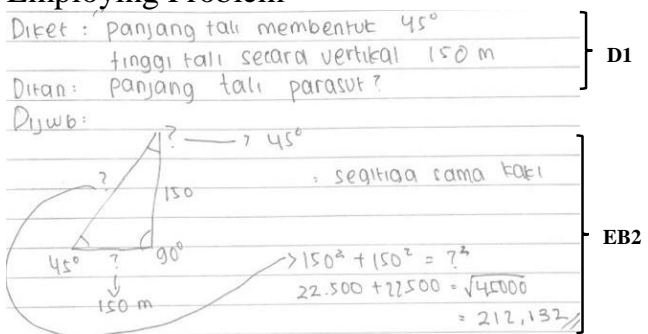

Figure 5. PU's Answer in Solving Employing Problem

Based on Figure 5, PU writes information that is known and asked to the problem, namely the angle and length of the rope vertically. Then PU wrote the question on the problem, namely the length of the parachute rope. PU illustrates the problem with the solution. Next, PU explained the solution more clearly in the interview.

Based on the interview, at the stage of describing the experience based on the problem, PU explained the problem in her own language. PU revealed the concept of this problem, phytagoras. PU stated that it had encountered this problem, this problem could be solved and it would be easy if it knew how to solve it.

At the phase of elaborating on experiences to form a resolution strategy, PU revealed the concept of the problem based on its experience of phytagoras and mentioned the link. PU stated the strategy used for this problem was triple phytagoras and gave reasons for choosing that strategy. PU stated the difficulty faced, namely finding root values because the value was large.

In the phase of analyzing experiences based on completion, PU explained the solution and the answer. PU revealed the strengths and weaknesses of the answers given that this method was less effective but simple. PU stated the way to improve the weaknesses owned by a more thorough way of doing the settlement

At the phase of evaluating experience based on the settlement made, PU is not sure of the answers given because they feel that they do not master the material. PU revealed a way to ascertain whether the answer was right or wrong by evaluating the formula used at the settlement.

c. Reflective Thinking Profile of PU in Solving Interpreting Problem

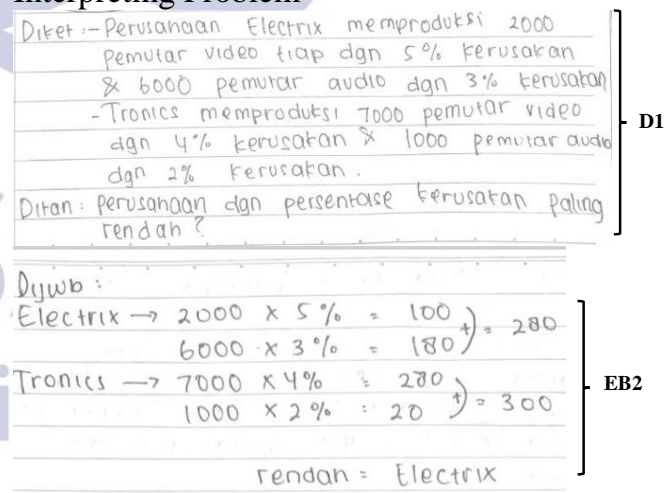

Figure 6. PU's Answer in Solving Interpreting Problem

Based on Figure 6, it appears that PU writes down information that is known and asked. PU does the settlement by counting many damaged products in each type and company. Similar to what LA did, on this issue PU has answered the problem but one step is needed to solve it, which is to calculate the percentage of the total of each company first. It can be seen more clearly the settlement made by PU in the interview transcript below. 
Table 9 . Transcript of the PU Interview on Employing Problem

\begin{tabular}{|c|l|l|}
\hline $\begin{array}{c}\text { Interview } \\
\text { Code }\end{array}$ & \multicolumn{1}{|c|}{$\begin{array}{c}\text { Interview } \\
\text { Excerpt }\end{array}$} & $\begin{array}{c}\text { Indicator } \\
\text { Code }\end{array}$ \\
\hline \multirow{5}{*}{ PPUI07 } & $\begin{array}{l}\text { Berdasarkan } \\
\text { pengalaman } \\
\text { yang kamu miliki } \\
\text { kira-kira konsep } \\
\text { atau materi } \\
\text { matematika apa } \\
\text { yang kamu } \\
\text { butuhkan untuk } \\
\text { menyelesaikan } \\
\text { masalah ini? }\end{array}$ & \\
\hline SPUI07 & $\begin{array}{l}\text { Ngitung } \\
\text { presentase aja } \\
\text { sih, menurut } \\
\text { saya. }\end{array}$ \\
\hline
\end{tabular}

Based on the interview transcript above, at the phase of describing experiences based on problems, PU revealed the problem with my own language. PU revealed the concept of the problem, which is about percentage. PU has encountered this problem, this problem is easy but the sentence is difficult to understand and the usual difficulty encountered is the lack of accuracy in entering calculated values.

At this phase, in elaborating experience to form a resolution strategy, $\mathrm{PU}$ revealed the concept of this problem based on its experience (SPUI07). PU only mentions one mathematical concept on this problem while LA mentions more than one concept. PU also chooses the formula and method for settlement and gives reasons for choosing that method. PU said the difficulties she faced in implementing this method.

At this phase, in analyzing experiences based on completion, PU explained the answers made. PU said it was experiencing confusion on this issue. PU revealed the way to improve his weaknesses by studying the material again.

In evaluating the experience based on the settlement made, PU revealed that the answer had not answered the question of the problem and provided a reason for it. PU stated that it had tried several times to resolve this problem in another way but remained unsure of the solution it had obtained. In accordance with Brown and Kanyongo's research (2010) that girls tend to be more persistent in solving problems than LA who tries to solve only once. PU revealed a way to convince herself whether the answers tended to be right or wrong by asking the more understanding ones.

\section{CLOSURE}

\section{Conclusion}

Based on the analysis of the results and the discussions that has been described above, we can be concluded as follows:
(1) Male and female students do all reflective thinking, (2) Male and female students overcome difficulties in solving problems, also difficulties in understanding the formula needed to solve the problem requested, and provide conclusions on requests given to problems (3) Male students cite mathematical concepts needed to solve problems, report strengths and weaknesses in every problem solving that is questioned and are confident of the answers they have given, (4) Female students provide other ways of solving problems, (5) Female students provide a picture explanation of the concepts they use, (6) Female students are less sure of the answers given to the problem.

\section{Suggestion}

Based on the results of the research that has been obtained, it is expected that teachers can more often practice reflective thinking on students to re-evaluate the material or concepts that have been learned. For other researchers who will conduct research relevant to this research, it is better to be able to reveal more deeply about the reflective thinking profile of students.

\section{REFERENCES}

Agustan, S., et al. 2017. "Reflective thinking in solving an algebra problem: a case study of field independent-prospective teacher". Journal of Physics: Conference Series, 893012002.

Brown, L. I. \& Kanyongo, G. Y. 2010. "Gender Differences in Mathematics Performance in Trinidad and Tobago: Examining Affective Factors". International Electronic Journal of Mathematics Education, Vol. 5 (3), hal: 114-130.

Demirel, M \& Derman, I. 2015. "A Study on the Relationship between Reflective Thinking Skills towards Problem Solving and Attitudes towards Mathematics". Social and Behavioral Sciences, $1972086-2096$

Dewey, J. (1933). How we think: A restatement of the Relation of Reflective Thinking to the Educative Process. Boston: Houghton Mifflin.

Hughes, A. G. \& Hughes, E. H. 2012. Learning \&Teaching Pengantar Psikologi Pembelajaran Modern. Bandung: Nuansa.

Juhaevah F. 2017. "Profil Kemampuan Berpikir Reflektif Siswa SMP dalam Memecahkan Masalah Matematika Standar PISA Ditinjau dari Perbedaan Gender". Prosiding SEMNAS Matematika \& Pendidikan Matematika IAIN Ambon, Vol. 5 (2), hal: 80-82.

Muin, A., et, al. 2017. "Analysis of Mathematical Reflective Thinking Skills Based on Learning Model and Mathematical Prior Knowledge". Advances in Social Science, Education and Humanities Research, Vol. 115 (3), hal: 21-27. 
Nuralam, N. \& Yani, M. 2019. "Tipikal Gender dalam Mengkomunikasikan Penyelesaian Masalah Matematika Sekolah Menengah Pertama". Prisma Sains: Jurnal Pengkajian Ilmu dan Pembelajaran Matematika dan IPA IKIP Mataram, Vol. 7 (2), hal: 100-112.

OECD. 2014. PISA 2012 Results: What Students Know and Can Do - Student Performance in Mathematics, Reading and Science (Volume I, Revised edition, February 2013). Paris: PISA, OECD Publishing.

OECD. 2014. PISA 2012 Results: What Students Know and Can Do - Student Performance in Mathematics, Reading and Science (Volume I, Revised edition, February 2013). Paris: PISA, OECD Publishing.

OECD. 2019. PISA 2018 Insights and Interpretations. Paris: PISA, OECD Publishing.

OECD. 2019. PISA 2018 Assessment and Analytical Framework. Paris: PISA, OECD Publishing.

Permendikbud No. 35 Tahun 2014 Tentang Perubahan atas Peraturan Menteri Pendidikan dan Kebudayaan Nomor 58 Tahun 2014 Tentang Kurikulum 2013 Sekolah Menengah Pertama/Madrasah Tsanawiyah. Jakarta: Kemdikbud.
Polya, George. 2004. How to Solve It: A New Aspect of Mathematical Method. New Jearsey: Princeton University Press.

Sugiyono. 2014. Metode Penelitian Pendidikan Pendekatan Kuantitatif, Kualitatif, dan $R \& D$. Bandung: Alfabeta

Suharna, H. 2018. Teori Berpikir Reflektif dalam Menyelesaikan Masalah Matematika. Yogyakarta: Deepublish.

Taggart, L. Germaine, \& Wilson, P. Alferd. 2005. Promoting Reflective Thinking in Teachers: 50 Action Strategies. (online) pada 13 Februari 2020.

https://books.google.co.id/books?id=cCC3t 1q0 7oC\&printsec $=$ frontcover $\& d q=$ Promoting + Refle ctive+Thinking+in+Teachers: $+50+$ Action+Strat egies\&hl=id\&sa=X\&ved=0ahUKEwjDr611 pra AhXCnZQKHeqMDEQ6AEIKzAA\#v=onepage \&q=Promoting\%20Reflective\%20Thinking\%20i n\%20Teachers\%3A\%2050\%20Action\%20Strate gies $\& \mathrm{f}=$ false.

Zhu, Z. 2007. "Gender differences in mathematical problem solving patterns: A review of literature". International Education Journal, Vol. 8 (2) hal:187-203.

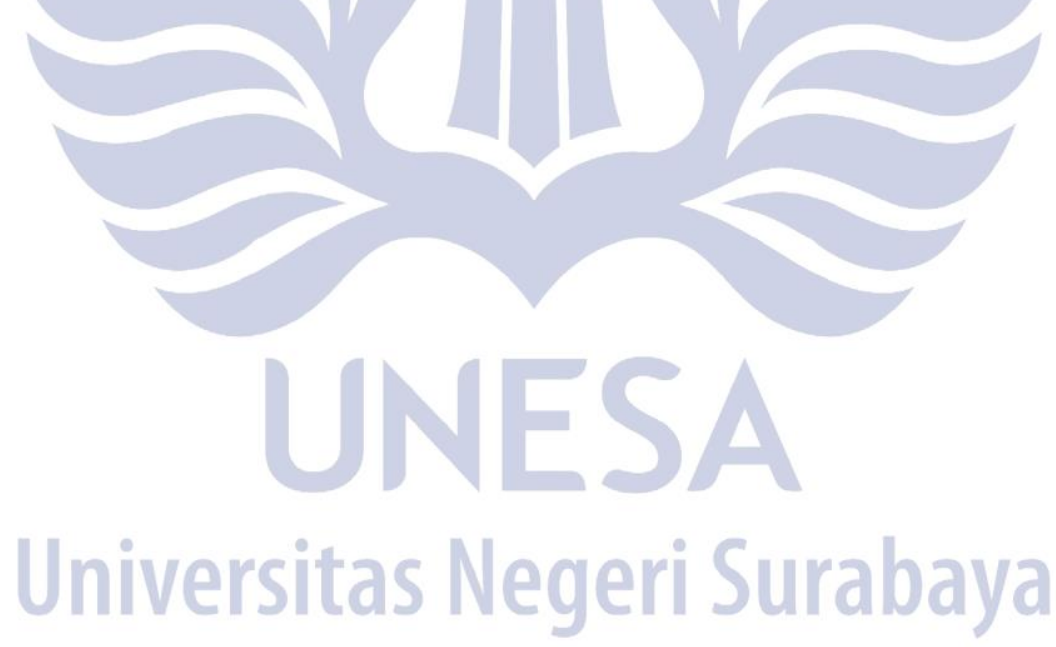

